\title{
Learning from Naturalisation Debates: The Right to an Appropriate Citizenship at Birth
}

Katja Swider and Caia Vlieks

Citizenship has a political and a legal dimension. In his opening contribution, Costica Dumbrava only marginally addresses the legal dimension of citizenship, acknowledging its importance, but suggesting that it is replaceable with alternative arrangements, such as a universal status for children. Maybe he is right in his priorities; maybe citizenship status should primarily be reserved for the purpose of fostering a political community. But in reality much legal baggage is attached to citizenship, and one cannot simply shake it off, even if this appears normatively attractive. In a way, the whole human rights movement can be seen as an effort to separate access to legal rights from possessing a status of political membership, and this attempt has not reached its goal (yet). As Jannis Panagiotidis points out, 'most so-called human rights are in fact citizens' rights'. Citizenship is still the 'right to have rights'. Avoidance of statelessness is therefore not just a legal whim; it is a human rights failsafe mechanism.

In our contribution we start from the assumption that leaving anyone, including (and especially) children, without a citizenship for any significant period of time is not an option due to the essential legal rights that are attached to the status of national citizenship. The question therefore is not whether children should acquire a citizenship at birth, but which citizenship they should acquire at birth. Should it be the citizenship of their parents? And if not, what alternatives to birthright citizenship arrangements are adequate?

While we consider attribution of citizenship at birth to be necessary, we also maintain that it is inherently unfair, regardless of what mechanisms of attribution are relied upon. There is nothing fair about attaching the fate of a child to one state, when states differ so tremendously in their ability (and willingness) to provide access to basic rights, such as education, healthcare, physical safety and pursuit of happiness for their minor citizens. Rainer Bauböck shifts attention from this unfairness by suggesting that 'we have to address the causes of global inequality directly' instead of criticising the 
contingencies of birthright citizenship. However, we should not forget that this discussion takes place largely among the privileged 'winners' of the 'birthright lottery'. ${ }^{1}$ There is no doubt that global inequalities need to be addressed, but is it morally justifiable to suggest to the 'losers' of the birthright lottery to wait for global equality?

If fairness in birthright citizenship cannot be achieved and leaving children without any citizenship is unacceptable, what is the normative ideal that we could strive towards in attributing citizenship at birth? As Lois Harder correctly argues here, rules about birthright attribution of citizenship are as politically charged as rules about acquiring and losing a nationality during adulthood, even though the former are not as much part of the public debate. According to Harder, '[t]he magical power of birthright citizenship is that it makes it possible for us to know and rehearse [politically charged] rules while simultaneously making birthright seem straightforward, static and apolitical'. Can we reverse this logic, and perhaps also learn from the extensively politicised discourse on migrants' rights to naturalisation in order to improve birthright citizenship rules?

In particular, we suggest applying the concept of appropriate citizenship to strengthen the normative foundation of birthright citizenship attribution. This notion is based on the ideas of Ernst Hirsch Ballin, who advocates 'a citizenship that is appropriate to everyone's life situation, where he or she is at home - which can change during the course of a person's life: a natural right to be recognized as a citizen, born free'. ${ }^{2}$ He believes that this type of citizenship and citizens' rights can overcome the existing gap between 'the universality of human rights' and 'the changing political and social settings of people's lives'. ${ }^{3}$ Drawing on that, we feel that appropriate citizenship, even when acquired at birth, could do the same. Appropriate citizenship is of course a highly subjective concept, the interpretation of which would be dependent on numerous cultural and specific national legal factors. Ensuring that birthright citizenship is appropriate would imply a case-by-case evaluation of the individual situation of each new-born, a process which in most cases would be as simple as the registration of birth, but in some cases would require a complex investigation to be conducted in a very brief period of time.

Shachar, A. (2009), The Birthright Lottery: Citizenship and Global Inequality.

Cambridge, MA: Harvard University Press.

2 Hirsch Ballin, E. (2014), Citizens'Rights and the Right to Be a Citizen.

Nijhoff: Brill, 145.

3 Ibid. 144. 
While perhaps logistically counter-intuitive, introducing the normative standard of appropriateness into the attribution of citizenship at birth is not more complex than trying to solve ad hoc 'hard cases' of citizenship within the traditional logic of ius sanguinis versus ius soli. This complexity of some birthright citizenship cases has been extensively discussed in the contributions by Dumbrava and Scott Titshaw. Requiring that birthright citizenship is appropriate emphasises the importance of (meaningful) ties ${ }^{4}$ of a person (including a child) to a country, and thus incorporates the idea of ius nexi discussed by David Owen. With the criterion of appropriateness we accept that birthright citizenship is a political issue, not a contingent biological fact of life, and therefore should be based in a reasoned decision-making process and subjected to normative criticism.

The requirement that citizenship acquired at birth needs to be appropriate is far from being precise. However, we believe that a certain amount of flexibility is necessary in order to ensure that attribution of citizenship at birth has a normative foundation in each individual case. The exact modes of implementation of the criterion of appropriateness would need to be developed within the individual legal systems, but important factors to be considered include the ones that have been discussed elaborately in this Forum discussion:

- the nationalities of the persons that are expected to care for the child (biological, social or functional parents or otherwise, thus including and reinforcing the ius filiationis proposal put forward by Bauböck);

- the country where the child is born;

- the country where the child is expected to build his or her future, receive education and effectuate his or her rights as a citizen;

- the necessity of ensuring that at least one nationality is acquired and that the best interests of the child are safeguarded (in line with the almost universally ratified Convention on the Rights of the Child). ${ }^{5}$

It is not always easy to determine all the relevant criteria for establishing appropriateness of citizenship with a high degree of certainty. Kerry Abrams, for example, identifies some possible obstacles when discussing Bauböck's ius filiationis proposal, namely that courts sometimes cannot determine who will ultimately be the parent that is truly (legally) responsible for the child. However, since the proposal of appropriate nationality is based on multiple relevant factors rather than a single one, the risks associated with the inability

4 Or 'genuine connection(s)', see also Nottebohm (Liechtenstein v Guatemala) ICJ Reports 1955, p. 4; General List, No 18.

5 See Articles 3(1) and 7 of the Convention on the Rights of the Child. 
to assess some of the factors are ameliorated by the availability of other factors that can compensate for uncertainties.

Finally, we would like to emphasize that Hirsch Ballin's ideas and the concept of appropriate nationality that we have introduced are compatible with having multiple nationalities, as well as changing one's nationality over the course of one's life. It is appropriate to enable children, as well as adults, to acquire a new nationality to reflect the changes in their personal circumstances. When attributing an appropriate nationality at birth to a child, states therefore do not need to embark on the impossible task of predicting the future.

Open Access This chapter is licensed under the terms of the Creative Commons Attribution 4.0 International License (http://creativecommons.org/licenses/by/4.0/), which permits use, sharing, adaptation, distribution and reproduction in any medium or format, as long as you give appropriate credit to the original author(s) and the source, provide a link to the Creative Commons license and indicate if changes were made.

The images or other third party material in this chapter are included in the chapter's Creative Commons license, unless indicated otherwise in a credit line to the material. If material is not included in the chapter's Creative Commons license and your intended use is not permitted by statutory regulation or exceeds the permitted use, you will need to obtain permission directly from the copyright holder.

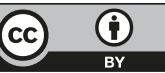

